\title{
The Myth and Reality of the Restructuring of Public Service in Nigeria
}

\author{
Aminu Mohammed Lawan, Razlini Mohd Ramli, Siti Zuliha Razali
}

\begin{abstract}
The Nigerian public service is revising the course of governance and presenting more robust and more viable systems of providing amenities to the public and working actively on its foreign affairs to reinstate investors' confidence. It is a machinery of executing policies and programs. Apart from this crucial function, it also provides services through the Ministries, Department, and Agencies. Many decades ago, the said services were inadequate in terms of how they are delivering. However, to further toughen its determination in implementing the federal government national development plan in the country. Office of the head of service of the federation has taken a critical look at its performance towards building and developing the capacity for civil servants and effort to create employment through various entrepreneurial and skill acquisition programmes. The primary objective of this paper is to scrutinise the myth and reality of the restructuring of public service in Nigeria. The study used a systematic literature review (SLR) as a methodology, the author searched document from the journal database, i.e. google scholar and library catalogue using different terms and synonyms, relevant articles found and critically review. The screening has conducted which exclude predatory papers because of the low quality of the journal. The related studies were selected and included in this study base on these criteria: Journal articles must be peer review, indexed by SCOPUS or web of science. It must not be too older in years of publication, qualitative and quantitative study design can be accepted; the geographical location is mostly developing countries. It comes out with the methodological result on the restructuring of public service in Nigeria. Finally, this study recommends the need to improve and provide the conducive working environment for workers in the public sector in Nigeria.
\end{abstract}

Index Terms: Myth and Reality, Restructuring, Public Service, Nigeria.

\section{INTRODUCTION}

Restructuring is the course of growing or reducing the number of element parts that constitute a structure and reconsidering the interconnection between them in a way that the whole system performs most proficiently. Restructuring from the perspectives of contemporary scientific exploration is the process of civil service reorganization. Which is to say, if the overhaul of the civil service takes a little potential on revolution or modification, thus it is the tangible approaches of remodelling the public service through physical reshuffle of its rudimentary units. Rearrangement in public services has only currently arrived at widespread and political discourse.

For a long time, Public services have been viewed as a

Revised Manuscript Received on September 22, 2019.

Aminu Mohammed Lawan, School of Social Sciences, Universiti Sains Malaysia. Penang, Malaysia,. aminuhadi2@gmail.com

Razlini Mohd Ramli, School of Social Sciences, Universiti Sains Malaysia. Penang, Malaysia.

Siti Zuliha Razali, School of Social Sciences, Universiti Sains Malaysia Penang, Malaysia. permanent entity with its operational way of engaging employee, handling human resource and community discourse (1).

Moreover, restructuring is today listed as a plan of public services of the developing nations Nigeria inclusive and is determined by a series of influences such as the economic downturn and the federal debt. Some measures like decrease in national expenses, services objectification, justification of funds are at risk in numerous nations. Services render in public sectors differ, in particular nation-states, the public sector is largely composed of civil servants, although in some occupation the number of public employees hired is lesser. The kind of the establishment might also vary significantly as the government division can comprise: public corporations, federal governments, local governments, health centres, educational institutions, railways facilities, etc. Nigerian Governmental service has full-grown significantly in recent time. The economic intervention of the state is excessively massive because joined regime expenses increased to $50 \%$ in 2001 from 29\% of GDP in 1997 (2).

Restructuring and remodelling some public sector units to justify structures and rise cost-effectiveness was continuing many years ago. Even though, regime responses and improvement on fiscal reform have differed substantially, yet, public sector restructures programs have a full agenda to address (1). The usual answers to public sector administration discrepancies in third world states focused mainly on a mixture of procedural efficiency-driven reorganizations built on neoliberal capitalist agenda and New Public Management (NPM) ideologies and apparatuses. These study analyses are leading themes in the arguments revolving around the public sector, and regime restructurings highlight some evolving responses to the queries posed at this point. This paper study the element and procedure of public sector restructurings, and the technical parts integral in donor-recipient countries relations positioned on transformation strategy and implementation (3). This paper judgmentally analyses the existing hitches of the Nigerian public sector in contrast to the background of current and the past efforts by the administration to execute necessary improvements. The main target of the research is to scrutinize the myth and reality of the restructuring of public service in Nigeria.

\section{REVIEW OF THE LITERATURE}

Several efforts have been made by researchers to coin the definition and essence of public service reform. Fundamentally, some authors maintained that public service 
of emerging nations is total and the most significant impetus of advancement by rendering an effective service, whereas in similar vein its ineptitude generates the substantial landmarks of any nation (4); Borins, 1994). To others, restructuring means a thoughtful and strategic change (Halligan, 1997; Denhardt \& Denhardt, 2000). For them, any interference that did not bring important variations in such a manner government service works and exercise her functions remains non-restructuring. However, public service restructuring is an organized interference designed at refining the establishment, actions, schemes, a process in governmental services to permit its revolution as the involved representative of modification, as an authentic tool of state harmony, societal and economic advancement. Also, reform needs an emphasis on filtering the quality basis of government sector engagement and altering the motivations that particular employees encounter, straightening along with the general rule and goals of regime.

\section{A. Public Service Restructuring: Myth and Reality}

Restructuring focus on managing the labour force and job conditions in a specific working environment and employment standing (public servants and government workers). It is firmly associated with images of the forthcoming of public services, the role, and delivery of public-private partnerships, a pre-emptive debate of scope, necessities, and sustainability of public services. By the way, it would comprise a broader sequences participants such as social allies, the national, service providers and the public, a procedure in which the mass media can perform an essential part (5).

Levy (6) recommends a good-fit sketch for administration restructuring that reflects transformation approaches with government forms. The rule classification varies in double extents: authoritative against antagonistic political bargain, and individual versus nonpersonal organizations. To ensure ranking necessarily appropriate, he manages these concepts as a nonstop, that integrates practical governmental and organizational changing. He then dichotomizes public service reorganizations in relations to the degree to which they are aiming at all-inclusive or progressive variation, and whichever their connections are based on principal-principal or agent-principal. This effort leads to some classes of restructuring: systemic public administration reorganization, goal-oriented transformations in specific departments, consolidation of checks-and-balances agencies, and enhancing numerous-partner administration. He afterward charts these restructuring forms to the categorization of political and establishment settings, that offers a foundation of defining a good fit.

Levy's piece develops applied the comprehensive meaning of public service reorganizations to "go with the grain," adjust to situations. His debate identifies the adjudicative calculation that governmental leaders assume in determining the kinds of public service restructurings to adopt, that helps to brighten nation possession. He is cautious about stipulating that his outline is not a new design for reorganization, instead aims to categorize the highest suitable and practicable changes to adjust and amend reform plans built on education. Hence, Levy's agenda is placed in the
post-NPM components of mutually repetitive and flexible procedures and specific/cooperative agency. His outline signifies an important influence on sanitizing good-enough governance reform tactics (3).

The reorganization increases a regime expenditure in China as empirical data indicates: Government budget spending for social services like obligatory schooling has been growing; this scheme shall significantly encourage public service building. Because the maximum fiscal resources offered at different branches of administrations, the worth and extent of public services mostly rest on the budgetary expenses of the regimes. Notably, budgetary expenses of education have progressively enlarged in current years. Statistics from 1992 to 2012 presented that the segment of total budgetary spending expanded by education increased slowly. In 1993, the Chinese government set aside a goal specifying that fiscal expense of education would stand at $4 \%$ of the entire GDP. It worth $2.46 \%$ in 1993 , considerable lesser than an average global level at that moment. Lastly, in 2012, higher than 2.2 trillion yuan (RMB) was assigned to the educational organization, amounting to $4.28 \%$ of entire Gross Domestic Product at a period in the Peoples Republic of China (7). Researchers like Raiser (1998), Ziying and Xin (2014) they distinguished that a regime's critical thoughts in respect to allocation expense arrangement had politically influences such as safeguarding national steadiness \& dropping a confrontation of pressure groups. Fairness of public service provision is mostly not of first importance in the formulation of rules.

\section{B. The Reform in the Nigerian Public Service.}

Public service restructuring programs in Nigeria "instead of progress and development which we have entitled to expect from those who governed us. We experienced in the last one and half decades particularly in the last regime, the persistent deterioration in the quality of our governance, leading to inability and the weakening of all public institutions" NEPA, NITEL, Education, Housing, some social organizations are let to decline and breakdown (8)p.132). A statement reflects the condition of disorder and immediate desolation that categorized the majority of political establishments aftermath of the 1994 restructuring by Ayida panel. External to inherent ambiguities related to the findings and execution subsequently. There are mass issues that further multiply the trouble of federal apparatus and more to the national civil service (Abba, 2007), (9)

The connection among political bureaucrats, public employees, and peoples was complicated with distrust, bribery, and immaturity (Jega 2007). Incompetence in the provision of basic amenities, selfishness to overall wellbeing, in consequence to a policies superintendent the behaviour of public officers and widespread fraud (10).

Bayo (11) explain reform revitalization of the Obasanjo regime as follows: retirement fund transformation, the monetization plan, reorganization of trial organizations, divisions, and directorates, rationalizing, workforce improvement. In addition to public procurement, and the rule of law, salaries modification, and rewards by 
Public Service Rule 2010. The restructuring tendencies of the Obasanjo's administration precisely directed by the ideologies of a shift to a real market system. To attain the fundamentals of the revitalization program, the Bureau for Public Enterprises (BPE) was created and understood to be a plan in realizing the restructuring agenda. Its mandate is guaranteeing smooth changeover to a capitalist system.

The plans which would convey important transformation in the civil service, has the following priority areas namely: re-design and re-launch of three core-training modules, to expand staff capabilities and skills over well-earmarked and sponsored programs across all cadres; the unveiling of Premeditated Finding of Recognized Skills to engaging outside talents from the business sector to determining high-level influence in the restructuring zones over partnership; goal-oriented institutionalized performance management to augment excellence in the civil service; propel corporate novelty in service through devoted innovation sections created in the Ministries, Departments, and Agencies (MDA); inaugurate Efficient, Productive, Incorruptible and Citizen-centred (EPIC) ethics revolution for better values-driven civil service. Though, there is also an emphasis on launching an enterprise content administration answer for digitalization of data and automatic workflow across the establishments; to unveil a wage increase in the public service that is attractive and workable for employees.

Meanwhile, the restructuring is a course of implementing variation to make things operates well. It is an intentional and orderly interference designed at creating an important change concerning novelty, transformation and attitudinal reorientation in terms of standards and service conveyance. The underscoring motive for reorganization in the public service is the pursuit to convey upgrading mutually the methods and eminence of service distribution. Any struggle directed toward job enhancement, in terms of retraining, reequip, delivery of necessary amenities, the elevation of helpful posture and psychological superstructure could be designated as reform creativity (12).

The public service in Nigeria has undergone a sequence of restructurings before independence and after independence periods. The post-independence country's public service could portray the establishment as an administrative adjunct of the governing military junta that conquered the political scene of the nation. Throughout the era, the philosophy of impunity was deep-rooted in the service, as evident in the draconian disengagement of numerous thousand civil servants in 1975, on weak grounds without due process. Nevertheless, the incident released a disturbing scourge of uncertainty on the soul of the Nigerian public employees who commenced a sole method of defensive attitudes to lessen the impending occurrence of such an unfortunate incident. No hesitation several restructurings had then been executed in the service that had led to the reduction or retirement of quite a lot of civil servants ostensibly on the grounds of plan. (12).

The Problems of the Nigerian public Service are as follows: Destruction of Public Service Standards; Ageing Labour force; Poor Succession Planning; Weak or Unsuitable Organisational Structures; Fruitless Work Operations and Systems; The Great number of Ghost Workers; Absence of transparency in Purchasing and supply, Planning, and
Bookkeeping Systems and Process. To clarify how public service system can be enhanced through the application of electronic governance, there is a necessity to scrutinize those issues that bring an obstruction to its decisive execution. Preceding researches have exposed that electronic governance acceptance could improve public service conveyance in Nigeria, to the degree that the problems constraining electronic governance operation like absence of social amenities, lack of adequate knowledge of ICT by public officers, and inadequate maintenance culture of the civil servants are address (13).(14)

\section{METHODOLOGY}

This study employs the Systematic Literature Review as a methodology; the relevant materials are review from the secondary sources, i.e. journals, books, and another source. Meanwhile, the author searched the document from the journal database, i.e., google scholar and library catalogue using different terms and synonyms, relevant articles found and critically review. The screening has conducted which exclude predatory papers because of the low quality of the journal. The related studies were selected and included in this study base on these criteria: Journal articles must be peer review, indexed by Scopus or web of science. It must not be too older in years of publication, qualitative and quantitative study design can be accepted; the geographical location is mostly developing countries. It comes out with the methodological result on the restructuring of public service in Nigeria.

\section{FINDINGS}

There are scarcely a regime branch or department which has not practiced or continues to experience reorganization. Many have been denationalizing, but others, like the government bureaucracies, have challenged with a burden to cut costs and raise efficiency. Whatsoever the rationale behind the policy, the furthermost important outcomes is idleness or redundancy (15).

Preferably, the layoffs are discretionary, but sometimes they are obligatory. Moreover, there are employees who exit the public service after 2 or 3 decades of perceiving nothing different, and for those looking for temporary employment, entrance into the business world can be a tremendously challenging experience (16).

The findings reveal that the restructuring of Nigerian public service has these achievements through the Office of the Head of the civil service of federation (OHCSF) under these importance areas comprise: the provision of required infrastructure for the launch of the Human Resource (HR) Module of the Integrated Personnel and Payroll Information System (IPPIS). The Human Resource module is to supplement the payroll element of the IPPIS platform to guarantee correct data of all civil servants and decrease leakages.

\section{CONCLUSION}

The target of greatest public service restructurings is to convert the ineffective public 
service to a skills-oriented, specialized and responsible structure, timely execution, hardworking and efficient function to the people. With the introduction of the reform agenda in public service, to improve the performance and efficiency of the state, the apparatus of state governance is rationalized and strengthened. The Restructuring of public service in Nigeria is the challenging mission that would not be regarded as an immediate answer to hitches working contrary to general progress. Forming political alliance backing of public sector reorganization to comprise all participants and allies like public service, employee associations, government workers, a press, nongovernmental associations, political parties, and the researchers is essential if we need a genuine restructuring.

It is also likely to conclude with the greatest of the approaches followed by the Nigerian government to reform the public service has not yielded the desired results, fundamentally because of political, historical, financial, organizational, social and ecological problems. The execution of restructurings characterizes the progress of the civil service reform. The civil service as the primary mechanism, by which the potentials of a healthier living could be realized, essential indeed be the central component of general consideration. And its revolution shall be a fundamental rule imperious of the government in control. The paper suggests the need to conduct more robust restructuring especially in Information and Communication Technology (ICT) adoption in the public service to attain a result-oriented goal and fight corruption. It also recommends the necessity for improving and providing the conducive working environment for workers in the public service in Nigeria.

\section{REFERENCES}

[1] Ehiyamen O. Administrative and Financial Reforms in the Nigerian Public Sector. Journal of Public Administration, Finance and Law. 2017(11):37-48.

[2] Makinde T. Problems of policy implementation in developing nations: The Nigerian experience. Journal of Social sciences. 2005;11(1):63-9.

[3] Brinkerhoff DW, Brinkerhoff JM. Public sector management reform in developing countries: Perspectives beyond NPM orthodoxy. Public Administration and Development. 2015;35(4):222-37.

[4] Bangura Y. Public sector restructuring: the institutional and social effects of fiscal, managerial and capacity-building reforms. Geneva: Geneva 2000 Occasional Paper; 2000.

[5] Bergström O, Henry L, Köper B, Rego R, Rodriguez R, Sprenger W, et al. IRENE network, Restructuring in the public sector, crisis social dialogue and innovations, Renewals project. In: Union E, editor. Cahier2013.

[6] Levy B. Working with the grain: Integrating governance and growth in development strategies: Oxford University Press; 2014.

[7] $\mathrm{Xu} \mathrm{G}, \mathrm{Wu}$ Y. Basic public services and the restructuring of the public finance system in China: Retrospect and prospect. Asian Education and Development Studies. 2016;5(4):438-53.

[8] Obasanjo O. An Address delivered during the inauguration of the National Council on Privatisation at Presidential Villa. Abuja on. 1999;20.

[9] Fadiya SO, Saydam S, Zira VV. Advancing big data for humanitarian needs. Procedia Engineering. 2014;78:88-95.

[10] Olaopa T. Theory and practice of public administration and civil service reforms in Nigeria: Spectrum Books; 2008.

[11] Bayo OA. Federal civil service reform in Nigeria: The case of democratic centralism. Journal of Radix International Educational and Research Consortium. 2012;1(10):1-45.

[12] Magbadelo JO. Reforming Nigeria's federal civil service: Problems and prospects. India Quarterly. 2016;72(1):75-92

[13] Abasilim U, Gberevbie D, Ifaloye O. Attaining a Better Public Service Delivery Through E-Governance Adoption in Nigeria. 2016.
[14] McGowan V. Improving institutional report card indicators. International Journal of Education and Development using ICT. 2016;12(1).

[15] Shanmugapriya D, Padmavathi G. A survey of biometric keystroke dynamics: approaches, security and challenges. arXiv preprint arXiv:09100817. 2009.

[16] Campbell I. Public sector restructuring: the human dimensions. Management Development Review. 1996;9(4):23-5.

\section{AUTHORS PROFILE}

I am Aminu Mohammed Lawan, currently my affiliation is School of Social Sciences, Universiti Sains Malaysia. Penang, Malaysia. My area of interest is Public servicing aminuhadi2@gmail.com

My name is Razlini Mohd Ramli, my current affiliation is School of Social Sciences, Universiti Sains Malaysia. Penang, Malaysia. i am interested in Learning.

My name is Siti Zuliha Razali and my affiliation is School of Social Sciences, Universiti Sains Malaysia Penang, Malaysia. my area of interest is

Public servicing. 